\title{
VILDE KUI MALTSVETLUSE KONSTRUEERIJA
}

\author{
RIHO SAARD
}

$\mathrm{E}$ duard Vilde romaan „Prohvet Maltsvet” on jäänud eesti kirjanduses ainsaks proosateoseks, mis kirjeldab ja kommenteerib XIX sajandi usulist rahvaliikumist. Vilde sõnul sai ta idee ja tõuke prohvet Maltsvetist romaani kirjutamiseks aastatel 1900-1901 „Mahtra sõja” jaoks materjali kogudes. „Ma annan algatuse-au rõõmsa uhkusega rahvale, kelle vaimline erksus mulle mu töö juures rohkem abiks oli, kui miski muu," on ta öelnud oma ajalooliste romaanide valmimise kohta (Vilde 1909). 1904. aasta septembri alguses avaldas Vilde Uudistes palve saata talle usaldusväärseid mälestusi Maltsveti isiku, tema õpetuste, usulise tegevuse ja Krimmi väljarändamise kohta (Vilde 1904). Kirjanikul õnnestus saada oma kasutusse kaks käsikirja. Joosep Freimanni ja Gustav Maltsa käsikirjadest said romaani põhiallikad.

Autorid, eriti Freimann, keskendusid põhiliselt Juhan Leinbergi isikule, mitte niivõrd Maltsveti-liikumisele. Maltsa käsikirja geneesi põhjalikult uurinud Juhan Käosaare hinnangul oli autor käsikirja hakanud mälu ja juttude järgi koostama 1890. aastatel Simferoopolis. Viimast versiooni hakkas ta kirjutama pärast romaani ilmumist 1908. aasta suvel (Käosaar 1961: 86), seega rohkem kui kolmkümmend aastat pärast Maltsveti-liikumise algust. Maltsa on tema teistkordselt kirja pandud mälestuste koostamisel mõjutanud ka juba ilmunud romaan ise. Joosep Freimann oli Maltsveti surma ajal kaheteistkümneaastane ja on käsikirja koostanud peamiselt oma isa Hans Freimanni ja teiste Maltsveti kaasaegsete mälestuste põhjal umbes kaheksateist aastat pärast prohveti surma (Käosaar 1951: 692).

Maltsa esimene käsikiri, mida Vilde romaani kirjutamisel kasutas, jäi kadunuks. ${ }^{1}$ Vilde ei ole aga teadaolevalt 1929. aastal ilmunud romaani redigeeritud versioonis Maltsa aastail 1908-1917 koostatud uut käsikirja kasutanud, mistõttu on romaani võrdlemine selle käsikirjaga Käosaare arvates seotud suurte küsitavustega. 1961. aastal artiklit lõpetades pidas ta siiski oluliseks, et uus käsikiri vääriks edaspidi sügavamat läbitöötamist veel mitmest aspektist (Käosaar 1961: 88). ${ }^{2}$

Malts ise on kinnitanud, et Vilde romaanis loodud tegelikkus ei kattu suures osas tema mälestustega (Malts - EVM 2002, Ar 1785, 1 259; Kruusberg 1931: 440-441, 443; Käosaar 1961: 88). Freimann see-eest on väitnud, et Maltsveti isiku kujutus romaanis vastab tema kirjeldusele. Samuti sabaga

${ }^{1}$ Käsikirja kadumisega seotud küsimused vääriksid eraldi uurimist. On võimalik, et see on sattunud Soomest Venemaale. Juhul kui käsikiri oleks Vildelt Soome piiri ületades ära võetud, võinuks see sattuda Soome Sandarmivalitsuse arhiivi (Santarmihallituksen arkisto). Osa selle arhiivi ainestikust hävitati 1917. aastal, osa viidi Peterburi ja osa jäi Soome. Suurem osa Soome jäänud säilikutest loovutati aastail 1926-1927 Nõukogude Liidule ning Soome jäänud väikeses osas (u 2 riiulimeetrit) Vildele kuulunud materjale ei ole (Helena Mörsky (Information Services Secretary National Archives) e-kiri Saardile 5. VII 2014).

${ }^{2}$ Praeguseks on Gustav Maltsa teine käsikiri „Ajalugu Maltsveti usust ja Krimmi rändamisest" koos Vello Paatsi kommentaaridega ilmunud ajakirjas Tuna (Malts 2011; Paatsi 2011) ja Rutt Hinrikuse lühema publikatsioonina Methises (Malts 2010). 
tähe lugu, peatüki „Karjane ja kari” algus ning ka romaani viimane peatükk pärinesid tema käsikirjast „Prohvet Maltsveti kolm viimast eluaastat” (Kruusberg 1931: 445).

„Prohvet Maltsvet” hakkas järjeloona ilmuma 1905. aasta märtsis Tartu ajalehe Uudised jutulisas Uudiste veste-osa (Vilde 1905). Tervikromaan ilmus trükist 1908. aastal (tiitellehel ekslikult 1906). 1908. aastal rõhutas Vilde kirjas Bernhard Lindele, et tema romaan on poliitiline romaan: „Minu plaan oli „Maltsvetist” „mosaiikromaani” teha: sinna sisse lüürilist luulet, dramaatilist paatost, tantsivat följetoni, poliitilist-sotsiaalset kainust, nalja jne. 1 ä b i s e g i panna - ikka seejärele, kuidas peatüki aine seda nõuab või välja kannatab. Mina ei pea seesugust käsitlemist sugugi „k e e la t u k s”, nagu ma üleüldse iga sk ola stili s e kitsenduse vastane olen" (Vilde 1957: 355).

\section{Maltsvetluse konstrueerimine läbi uuestisündimise mõiste}

Soome realistlikule kirjandusele aluse pannud Juhani Aho kirjutas Soome ärganutest mitu teost, ${ }^{3}$ milles ühinesid rahvuslik ja usuline äratus. Tõlgendus äratuskristlusest kui rahvusliku ärkamise eelkäijast, mis aitas vastu panna Vene hegemooniale, sai Soomes eriti rootsikeelsete hulgas terava kriitika osaliseks (Huhta 2001: 119, 179-180). Vilde ei pakkunud eestlastele oma Maltsveti tegelaskujus midagi niisugust. Tema eesmärgiks ei olnud siduda Maltsveti usulist rahvaliikumist eestlaste rahvusliku ideoloogiaga. Maltsvetlus kui lokaalne usuline rahvaliikumine ei võrsunud mitte rahvuslikust identiteedist, vaid põhiliselt siiski rasketest sotsiaalsetest oludest, harimatusest ja rumalusest (Vilde 1929a: 5, 129-130, 170).

Maltsvetlaste kohta ei kasutata romaanis mõistet „ärganud”. See mõiste on seotud ainult Maltsvetiga. Tema on „hingeärataja”, ta „äratab rahvast”, peab „äratuskõne”: „Ärgake üles, sündige uuesti” (Vilde 1929a: 34-35, 88, 92, 209). Lõhmuse Taaveti naise Anu kohta öeldakse, et temas oli toimunud „usuline uuestisünd”, mis väljendus „valjus, julmas kombeusus”, mis „pani võõra vara puutumise iseäranis kange vande alla", nii et Anu viis oma abikaasa poolt mõisa aidast varastatud kraami tagasi ja andis ise ta kurjategijana üles (Vilde 1985: 204, 208).

Uuestisündimisega on Vilde toonud romaani niisugust usulis-teoloogilist keelekasutust, mida maltsvetlased Johannese evangeeliumi 3:3 põhjal arvatavasti tundsid, kuid iseennast nii ei määratlenud. Mõiste puudub ka Maltsa käsikirjas. Uuestisündimise mõiste tuli aktiivsesse kasutusse vabakogudustes, baptistide spiritualiteetlikus õpetuses. Eesti baptistidel oli selleks kasutada hiljemalt 1897. aastal tehtud tõlge Saksa baptistikoguduste 1847. aasta usutunnistusest, mille kuues paragrahv kandis pealkirja „Patuse uuestisündimisest ja ümberpöörmisest" (Baptisti koguduse Usutunnistus ... 1912; Saard 1995: 6-8; 1999: 6-8).

Uuestisündimisega seotud riitusi romaanis ei kirjeldata. Maltsvet ei seleta, kuidas uuestisündimine teoks saab. Ta ei seo seda kirikliku lasteristimisõpetusega, vaid näib mõistvat seda ümberorienteerumisena, vabaduselootusena, kus vabaks saab häda kannatav ihu (Vilde 1929a: 92). Kõigepealt orienteerub ihu oma soovidest lahtiütlemisele - tubakast, viinast, sealihast, vere-

\footnotetext{
${ }^{3}$ „Heränneitä” (1894), „Kevät ja takatalvi” I-II (1906).
} 
söömisest ja ihuehtimisest. Moraalsega liitub usuline ümberorienteerumine, vennastekogudusest ärapöördumine (Vilde 1929a: 81-108, 112-118). Kuusalu vennastekoguduslasest köster Gustav Sandberg kirjutab oma mälestustes, et Maltsvet öelnud: „need kõik kahe naese pidajad olema, kes palvemajas käivad. Kirik on õiguse naene, aga palvemaja on oora naene. Selle läbi oli palju Kuusalus vendade seltsist lahkund" (Gustav Sandberg: EELKKA). Maltsveti suhe vennastekogudusega on arenenud juba päris algusest peale konflikti suunas. See vastasseis võis olla põhjustatud ja areneda avalikuks konfliktiks endise mölder-kõrtsmiku egotsentrilisest teistele allumatusest ja sellest, et teda jäeti ootama koguduse täisliikmeks vastuvõtmist (Ader s.a. VII: 766-767).

Maltsveti ja maltsvetlaste side kirikuga oligi ambivalentne. Maltsvet kutsus käima agaralt kirikus ja armulaual (Malts: EVM 2002, Ar 1785, 1 133p). Teisalt teadis Jannsen kirjutada, et kui Maltsvet 1858. aasta septembri lõpus Paides vahistati, siis polnud ta juba kolm aastat armulaual käinud (Järwa walle-prohwet 3. 1858). Maltsveti vanem poeg Gustav oli käinud enne Simunasse siirdumist 1864. aasta septembris viimast korda Paides armulaual 1860. aasta 1. aprillil (EAA 3159.1.117, kaader 51). ${ }^{4}$ Vilde teadis, et maltsvetlased ei käinud 1860. aastal Järva-Madisel enam armulaual, sest pastor keeldus rinnast võtmast oma ametiristi, mida maltsvetlased pidasid „sõjaristiks”. „Ega kirikuõpetaja sõjamees ole, et tal on sõjarist kaelas, ja ega me hakka sõjamehe ja kuldse Kristuse ees kummardama" (Vilde 1985: 235).

Simuna koguduse vaimulik Hugo R. Paucker kirjutas kirikukroonikasse, et maltsvetlased toetusid Vanale Testamendile, nõudsid kommete puhtust, kuid ei tahtnud midagi kuulda vaimulikest. Nad ei tunnistanud kirikupalvet ega pihti, ristisid oma lapsed ise ning eemaldati nii armulauaosadusest (Simuna... 2013: 134). Et maltsvetlased oleksid ise omi lapsi ristinud, teistest allikatest lugeda ei saa. Paucker võis selle kuulduse kroonikasse märkida 1858. aasta oktoobrikuu Perno Postimehest, kus Maltsvetti nimetati pilkavalt ristijaks (Järwa walle-prohwet 2. 1858). Vilde kirjutab: „Ühtlasi tekkis paiguti ikka enam kultuslikke lahkkombeid juurde. Nagu ristimisi ja laulatusi oma usu järele „üle tehti”, nõnda tuli ka sellelaadilisi laualevõtmisi ette....” (Vilde 1985: 320).

Maltsveti uuestiristimistest, laulatamistest ja kirikuvälistest armulaua jagamistest ei ole säilinud mingeid usaldusväärseid allikaid. See ei oleks jäänud 1858-1859 Maltsvetti ülekuulanud uurimiskomisjonile Riias teadmatuks. Iseendale jagatud armulauast kui vana mehe veidrusest räägitakse romaanis alles siis, kui Maltsvet Pruunal oma viimaseid elupäevi veedab (Vilde 1985: 503). Sel ajal olid kirikuvälised armulaua ja pühaõhtusöömaaja mälestussöömaajad tulnud juba laialt kasutusele, saades dokumenteeritult esimest korda alguse 1876. aastal Naissaarel (Protokoll... 1881: 5). Teadaolevalt oli PärnuJaagupi köstri poeg Lorenz Johannes Schwan esimene eestimaalane, kes ennast 1864. aastal lasi Peterburi saksa baptistikoguduses uuesti ristida ning sai endale 1865. aastal ajakirjanduses hüüdnime „Baptisti Maltsvet” (Usso seggamisest 1865).

Jõelähtme vaimulik Woldemar Fr. Kentmann nimetas Maltsvetti „nutikaks eestlaseks”, kes lõi „vagatsevate elukommetega inimeste sekte” (Jõelähtme s.a., lk 110-111). Välisest vagadusest asi siiski kaugemale ei läinud. Meestel käskinud Maltsvet pea kiilaks ajada, kõigil paastuda ja palvetades kummargile maha heita nagu moslemid (Järwa walle-prohwet 2. 1858; Wata,

\footnotetext{
${ }^{4}$ Kirikutäht on väljastatud 29. septembril 1864.
} 
mis rummalus teeb! 1. 1861). Ka sellesse ajalehest pärit teatesse tuleks suhtuda ettevaatlikkusega. Romaani jaoks on Vilde laenanud meeste pöetud pead just Perno Postimehest (Vilde 1985: 193).

Maltsvetlastevastane kriitika läks lõpuks üle antisemitismiks. 1861. aastal kujutatakse neid Perno Postimehe veergudel avalikult juutidena, kes ei söö sealiha, ei valmista sabatipäeval süüa, ei küta ahjusid ega talita loomi ja nimetavad ennast „noore Iisraeli sooks” (Wata, mis rummalus teeb! 2. 1861). Kuusalu koguduse vaimulik Eduard Ahrens, kelle ametiajal Maltsvet samas kihelkonnas elas, nimetas teda „valeprohvetiks”, kes põlastas luterliku jumalateenistuse mõningaid osi, eriti põlvitamist meieisapalve ajal ja krutsifiksiga altari ees (Kuusalu... 2014: 45-47, 202-203.) Maltsvetlaste eetiline rigorism puudutas ka liturgilist keelt. Maltsvet nõudnud, et nad ei laulaks jumalateenistusel kaasa koguduse vastulaulu „Meist meelehea on Jumalal, suur rahu põlv on taeva all”, sest see polnud tõsi - Jumalal ei saanud olla kellestki hea meel, ja maailmas ei olnud ka rahu (Wata, mis rummalus teeb! 1. 1861).

Baptistide liidu juhile Karl Kaupsile ei jäänud märkamatuks, et Vilde oli maltsvetluse spiritualiteeti konstrueerinud baptistliku uuestisünniõpetuse abil. Kaups tunnustas Maltsvetti kui „uuestisündinut”, kes sellele vastavalt kandis ka „märtrikrooni ja ketserikübarat”, mis pidid olema prohvetikutse eeldused. „Huvitavad on Maltsveti õpetuse välised nõuded. [---] Kõik kandsid ühesuguseid pikki halle rõivaid. ${ }^{5}$ Kirjude rõivaste kandmine oli keelatud. Juukseid ei tohtinud palmida. Need pidid lahtiselt langema kammitult üle õla. Seega maltsvetlik liikumus omas juba mõnda välist, mis hiljem viisiks tulnud vabakoguduslikus liikumises. Maltsvetlased olid küll ka vist Eestis esimesed, kes kandsid usulist vormirõivastist," arutles Kaups ja tunnistas maltsvetlaste ja vabakoguduslaste ajaloolist geneesi (Kaups 1936a: 134).

Kaups paigutas maltsvetlased eesti vabakoguduste kronoloogilisse ja spirituaalsesse sugulusteooriasse (vt Saard 2005: 9-28). Liikumine oli vaimselt kirikust lahus ja tegutses iseseisvalt selle kõrval. Paralleele võiks leida teisigi, nagu näiteks maltsvetlastele ja baptistidele ajakirjanduses osaks saanud pilkamistes. Äratusliikumiste ja neist väljakasvanud vabakoguduste ajalootõlgendusis on alati toonitatud uuestisündimise pärast kannatamist. Igale väiksemalegi kannatuseks määratletavale kogemusele antakse suurem tähendus, mis peab kuuluma kannatava usurahva üldpilti.

Kuigi Kaupsi hinnangul polnud „usku tema tõelises kujus... ükski suurem ning kaalukam ilukirjanduslik teos eesti keeles veel käsitlenud”, pidas ta „Prohvet Maltsvetti” just eelöeldu põhjal kõige usulisema sisuga eestikeelseks romaaniks. „Laiaulatuslikult ja sügavalt käsitletakse siin usuprobleemi. Haruldase asjatundlikkusega on uskmatu autor tunginud kõigisse vabakoguduslikkudesse usumõistetesse. See ei ole imestamisväärne, kui teame, et autor tol ajal $^{6}$, kui tal oli see teos käsil, külastas Tallinnas baptisti koosolekuid ja tutvus välismaa vabakoguduste vaadetega ${ }^{7}$. Nende muljete ning mõjutuste najal, mis

\footnotetext{
${ }^{5}$ Aleksis Kivi „Seitsmes vennas” (sm. k 1873, e.k 1924) on antud detailne kirjeldus Soome ärganute - keda nimetati körtideks (ett skört) - riietusest (meestel must-hallikas kuub ja püksid; naistel hallikassinine kampsun, seelik ja helesiniseruuduline pearätik), millest sai 1820-ndatel ärganute väline tunnusmärk (Kivi 2005: 362). Tegu oli lihtsa kodukootud kangast valmistatud riidega, mille kandmisega sooviti rõhutada oma sõltumatust härraste moest ja oma lihtsat eluviisi. Vt lähemalt Huhta 2001.

${ }^{6}$ Vilde tegeles romaani jaoks materjali kogumisega põhiliselt 1904. aastal (Viitol 2012: 347).

7 1904. aastal Tallinnas baptistikogudusi külastades oleksid võinud Vilde kätte sattuda
} 
tema sealt omas, andiski ta maltsvetlikule liikumusele selle värvingu. Nii on $\mathrm{P}$ [rohvet] $\mathrm{M}$ [altsveti] usuidee ilmale sündinud vabakoguduslikus vaimuõhkkonnas" (Kaups 1936b: 158, 160).

Ja veel: „Kui nii ilmalikus teoses... käsitleti piiblit autoriteetse jumalasõnana, palvetamist kujutati südamlikult innukana, otsiti pühitsust ja ilmalikest eraldumist, vaimuandidel lubati tegutseda, armastati Jeesust ja oodati teda tagasi, kuulutati igavese kohtu tõde; samuti Jumala armu ja hirmu, siis... jääb mulje, et Maltsveti isikus on meil tegu ülaltsündinud, vaimust-uuendunud mehega. Vaimust-uuendunud lugeja aimab seda, et teose autor ei näi aga midagi teadvat uuestisünni jõust, mille tõttu ta tihti seisab nõutult asjade ja sündmuste ees ja - langetab vääraid otsuseid" (Kaups 1936b: 132, 134, 158).

Vilde-uurija Livia Viitol mainib, et Saksamaal romaani kirjutades külastas Vilde seal sageli lahkusuliste jumalateenistusi (Viitol 2012: 32). Ühtegi dokumenteerivat allikat Viitol ei esita.

Simferoopolis külastas Vilde 1904. aasta oktoobris vähemalt ühel pühapäeval kohalike mennoniitide palvetundi, nagu ta on kirjutanud kirjas Linda Jürmannile (Vilde 1957: 324). Tallinnas võis Vilde kõige tõenäolisemalt külastada Mardi tänavale 1901. aastal ehitatud palvemaja ja kuulata seal priilase Hans Krabi ülivaimustatud kõnesid nägemustest, ilmutustest ja unenägudest, mis haaras rahvast, viis hõiskamisele ja hüppamisele (Ader s.a. VIII: 306). Taolisele usuekstaasile võib romaanis viidata lõik: „Sinu usk on nii kange, et ta ajab meeled segaseks... meeled segaseks ja aru pahempidi. Ta ajab keksima ja siputama ja hundiratast lööma ja tiritamme kasvatama. Ja need, kes pealt vaatavad, ajab ta naerule või haledusele - nõnna, kuda on kellegi süda. Ma ei usu, et sinu usk vanaks igab ja su kogudus suureks kasvab. Seks on su usk liiga kitsas - pigistab ja kägistab" (Vilde 1929a: 217-218). Vildel oli õigus. Ekstaatilised vabakristluse vormid pole kunagi leidnud eestlaste hulgas arvestamisväärset poolehoidu. Ka vabakoguduslik „kitsas usk” (Vilde 1929a: 212) on pakkunud hingamisruumi puudumise tõttu püsivat vaimustust ainult vähestele.

Samas on Vilde usklikud ,vägivaldsed fanaatikud... ja taeva poole vahtivad viimsepäeva ootajad. Terve nende asi on üsna saamatu ning Tõnu-Peetri Madis saab ilmutuse, et peab Jumala tahtel Lõhmuse Taaveti abikaasa Anuga sünnitama püha poja. [---] PM-i usklikud on põlgamise väärt veidrikud, kellest ainult mõned muutuvad uuesti normaalseteks, pärast usust loobumist” (Kaups 1936b: 159). Kaupsile sekundeeris Uku Masing: „Olgu selle romaani kirjanduslik väärtus kui suur tahes, Vilde haiglane vaen usu vastu on talle teinud võimatuks Maltsveti kui inimese mõistmise. [---] Vilde on just kõige grandioossemast läinud mööda üleolevalt, põlglikult ja pääliskaudselt, sest tal nähtavasti puudus võime mõista asju, mis on väljaspool argipäiseid sündmusi” (Masing 1993a: 113, 140). ${ }^{8}$ „Ideeliselt pole kirjanik suutnud sisse tunda maltsvettide usuellu, suhtub sesse tavalise „ilmalapse” kerge irooniaga, nähes peamiselt lahkusuliste väliseid, kõrvalseisjaile veidrana tunduvaid kombeid,"

brošüürid „Teekäija manna korjamisel”, „Teekäija Petelis”, „Teekäija Jabboki koolme juures”, mis sisaldasid välisautorite tõlkeid. Vildele võidi anda ka Moritz Geissleri teos „Die Baptisten, wer sie sind, was sie glauben und woher sie stammen, nebst ihren Eigenthümlichkeiten” (1871), mille eestikeelne tõlge ilmus 1885. aastal Danzigis („Baptistid, kes nemad on, mis nemad usuvad ja kust nemad pärit on, kui ka nende isisugused omadused”). 1928. aastal trükiti Keilas kordustrükk.

${ }^{8}$ Pikk artikkel „Prohvet Maltsvet” oli Masingul ta enda sõnul peaaegu valmis juba 1934. aasta juunis (Masing 2006: 233), see ilmus Usuteaduslikus Ajakirjas 1934-1937. 
tõdes ka Villem Alttoa (Alto 1935: 20). Sama rida jätkab Ilmar Vene, kelle hinnangul oli Vilde „nähtava tegelikkuse mõjukas kirjeldaja; psühholoogina ja mõtlejana ta nii silmapaistev ei olnud" (Vene 1987: 234; 1997: 53).

Vilde romaan ei sobinud päris niisugusena hiljem ka nõukogulikku kirjandusse. Leiti, et Vilde polnud piisavalt süvamarksistlik ja „tema ajaloolise materialismi tundmises on olulisi lünki” (Käosaar 1951: 689). Käosaar pidas ühtlasi vajalikuks märkida, et „romaanile oleks tulnud kasuks, kui... kogu teose käigus oleks veel teravamalt esile toodud religiooni kui ühiskondliku teadvuse vormi aktiivselt pidurdavat mõju rahva elu arengule" (1951: 708). 1953. aastal püüdis Tallinnfilmi režissööri assistent Priit Raudkivi (19201970) oma filmistsenaariumis „Prohvet Maltsveti” sisu ja ideearendust ateistlikumaks kirjutada. Raudkivi kirjutab Tallinna Kunstiliste ja Kroonikafilmide Kinostuudio direktorile 25. VI 1955 oma filmistsenaariumi „Viletsuse karavan” kohta: „Olen püüdnud täpsustada Ed. Vilde poolt loodud kujusid, muutes ühtlasi kogu romaani sündmustikku veelgi rohkem usuvastasemaks, seda peamiselt stsenaariumi teise osa arvel... näidates talurahva järkjärgulist vabanemist lahkusu kütkeist ja võitlust balti parunite vastu. [---] Selleks, et vähendada usulise ekstaasi momenti, olen vähendanud prohvet Maltsveti osa, kasutades vaid neid episoode, mis võimaldavad teda näidata kui kahtlematult osavat veenjat-kõnelejat, kuid kes seda kasutab enda huvides, jäädes hingelt selleks, kes ta oli - kõrtsmikuks. [---] Olen püüdnud leida võimalusi ja edasi arendada Ed. Vilde mõtteid väljarändajate vabanemiseks usuhullustusest" (ERA R-1707.1.139).

Usust ei loobu romaanis siiski ükski tegelane. Väites vastupidist, eksivad mõlemad, nii religiooni pooldajad Kaups ja Masing kui ka nõukogudeaegsed religiooni eitajad.

\section{Maltsvetlaste valge laev}

Maltsvetlaste pilve ja laeva ootamisest kirjutati ajalehtedes, et juba 1860 . aasta suvel olnud liikvel jutud sellest, kuidas maltsvetlased viiakse omal ajal taeva pilvedega ära ning Paides soovinud mõned purjelaevadega ${ }^{9}$ asuda üle mere teele õhtutaevas särava punase tähe suunas (Wata, mis rummalus teeb! 2. 1861). 1861. aasta 22. märtsil teadis Eestimaa kuberner Wilhelm Ulrich märkida, et maltsvetlased olid veendunud, et „sündsal tunnil pühavaim nad kas vahetult või ingli või prohveti näol ära viib sellelt maalt teisele, tõotatud maale" (Kruusberg 1931: 162). Sama aasta 25. aprillil Järva-Madisel koostatud visitatsiooniprotokollis märgiti, et Maltsvet olevat öelnud: „pühakud, kui neil on usku ja nad on pühitsetud, viiakse pilvel imeliselt tõotatud maale” (Kruusberg 1931: 195), 14. juunil oli Eestimaa kuberneril juba uus informatsioon selle kohta, et maltsvetlased uskusid, et keiser ise saadab neile Krimmi siirdumiseks auriku (Kruusberg 1931: 218, 234). Jannsen aga teadis kirjutada, et pilves äraviimine pidi toimuma 1861. aasta 23. aprillil, ja kui seda ei toimunud, siis pidi 25. mail Maltsvet ise kahe suure sõjalaevaga neile järele tulema (Kolmas kirri... 1861).

\footnotetext{
${ }^{9}$ Masing asendas mitmusliku vormi meelevaldselt ainsusega, luues nii eksitava ettekujutuse, et maltsvetlased ootasid ühte konkreetset taevalikku valgete purjedega laeva (Masing 1993a: 150).
} 
1861. aastal lahkus aurulaevaga ${ }^{10}$ Peterburi poole koos Maltsveti vennapoja Gustaviga ainult 23 perekonda, need, kelle passid tema käes olid (Malts: EVM 2002 Ar 1785, 1 319). Ülejäänud, umbes sada perekonda Järva- ja Harjumaalt, ,inimesed, kes kõik oma lootused ja terve tuleviku imedele olid rajanud, kohapidajad, kes kevadel vilja külvamata jätnud, oma loomad ja majakraami maha müünud, kindlas usus jumala sisse", jäid Tallinna maha (Vilde 1929b: 487). 27. juunil ei leitud Lasnamäelt enam ühtegi passita isikut ning ootajate hurtsikud lõhuti maha (Vassar 1975: 140).

Tegemist on olnud paljude kuulujuttude seguga. Väljarändamist soovinud perekonnad sattusid linnaelanike ja vaimulike pilke alla. Viimased pidasid kogu väljarändamist kuradist ajendatuks. Väljarändajad aga kaitsesid ennast piiblis kirjeldatud Iisraeli rahva väljarändamisloo abil kui piibellikult kõige õigema lahendusega (Malts: EVM 2002 Ar 1785, 1 289).

Kui valge laeva müüdi levik ja muutumised ajas on kergesti jälgitavad (Hinrikus 2014), siis müüdi loomeprotsess jääb dokumentaalselt rekonstrueerimata ja tõendamata. Simuna vaimulik Paucker ei maini kirikukroonikas sõnakestki maltsvetlaste laeva ootamisest, vaid märgib, et Leinberg kutsus oma sekti liikmeid Jeruusalemma siirduma, kuhu nad pidid sattuma ime läbi (Simuna... 2013: 134). Jõelähtme kirikukroonikasse on Kentmann märkinud, et „pilve peal pidi neid äraviidama, maailmalõpp pidi lähedal olema mis oli päevalise täpsusega kindlaks määratud" (Jõelähtme s.a., lk 111-112). Kohtupäev pidi saabuma 1858. aasta 12. juunil (Järwa walle-prohwet 3. 1858).

Usk jumalikku pilveimesse on eestlaste hulgas olnud väga elujõuline, mida aitasid elus hoida ka piiblipildid iidsete iisraellaste müütilisest väljarändest ja neid juhtinud pilvesambast (2Ms 13:21, 16:10, 4Ms 9:21, 5Ms 1:33) ning Issanda tulemisest omade juurde paksus pilves (2Ms 19:9). Aga samuti kristlaste hulgas laialt tuntud ja omaksvõetud uskumus, et uskujad muudetakse ja tõmmatakse enne viimsetpäeva üles pilvedesse, millega Issand neile järele tuleb (Mk 13:26, 14:62, 1Ts 4:17, Ilm 1:7, 11:12). Maltsvetlastele omistatud pilveteemat on 1866. aastal käsitlenud Georg Julius Schultz-Bertram rahvaluulelises luuletuses „Prohvet”, mis lähtus „rango pilve”11 ehk paksu pilve, nii nagu Wiedemann tõlgib (1869: 1022), ootamisest Lasnamäel (Schultz-Bertram 1866: 8-12). Veel 1881. aastal viis Lagedi koolmeister ja prohvet Karl Reits oma järgijad Ülemiste järve äärde pilve ootama, mis pidanuks nad „Kaananisse" sõidutama (Plaat 2001: 76).

Kuusalu koguduse vaimulik Eduard Ahrens ei teadnud kirjutada midagi pilve või laevaga Eestimaalt lahkumisest (Kuusalu... 2014: 45-47, 202-203). Valge laeva (das weisse Schiff) ootamisest kirjutab Kuusalu kirikukroonikas esimest korda 1869. aastal vaimulik Kentmann. Aga see valge laev on seal ülekantud metafoorses tähenduses ja pole seotud Maltsvetiga, vaid Eestimaa kuberneri Mihhail Galkin-Vraskoiga, kelle kantseleis registreeriti Kaukaasiasse väljarändajate nimekirju ja oodati valget laeva kui mingit kuberneri katteta lubadust (Kuusalu ... 2014: 62, 216).

Publitseeritud kirjasõnasse tõi Schultz-Bertrami paksu pilve asemel laeva kujundi Nõo koguduse vaimulik Martin Lipp. Pidi „üks laev tulema ja usklikud otseteed Krimmi viima”, kirjutas Lipp (1899: 183-184). Lipp ei nimetanud

\footnotetext{
${ }^{10}$ 1858. aastast sõitsid Peterburi ja Revali liinil aurulaevad Tetis, Admiral ja Leander (Pärna 1979: 54).

${ }^{11}$ Herbert Salu on „rango pilve” asendanud meelevaldselt Valge Laevaga (Salu 1981: 119).
} 
laeva valgeks. Kui laev olnuks taevalik, siis milleks üldse Tallinna kogunemise nõue, küsis tagantjärele Uku Masing (1993a: 150). Artur Vassar on tõdenud, et allikatest ei selgu, millal ja kuidas tekkis Krimmi välja rännata soovijatel kavatsus koguneda Tallinna sadama juurde (Vassar 1975: 138-139).

Valge laev, mille „kroonu jumala käsul” ootajatele järgi saadab, jõuab kirjandusse ja sealt laiadesse rahvahulkadesse alles Vilde romaani kaudu (Vilde 1929b: 488-489). Gustav Malts kirjutas: „Kõige naljakam oli jutt väljarändamise kohta, kus suurvürst [Vene laevastiku kindraladmiral] Konstantin [Nikolajevitš], kes suure väe üle sel ajal oli, et see pidi inimesed laevaga ja viimselt „valge laevaga” üle mere (läbi Vahemere) Krimmi viima. Valgest laevast sai viimaks valge pilve, mis vagad rändajad pidi ülesse tõstma nagu Jeesuse Õlimäe peal, ja tõotatud maale viima!" (Malts: EVM 2002 Ar 1785, 1 289-293). Maltsa kirjeldust mööda olevat maltsvetlastest väljarändajad oodanud laeva, siis valget laeva ja kõige lõpuks valget pilve. Pilve ja laeva genees on Maltsal vastupidises kronoloogilises järjestuses ega lange kokku primaarsetes allikates esitatuga, kus pilv oli esimesel kohal. Malts ei eita, et ootamine ei olnud seotud ka valge laeva ootamisega, aga annab aastatel 1908-1917 koostatud teises käsikirjas sellisele laeva- ja pilveusu jutule hinnangu - tegemist oli kõige naljakama jutuga.

Ka ajaloolane Aleksander Kruusberg paigutas valge laeva loo oma lapsepõlves prohvetist kuuldud „imelike lugude” hulka (Kruusberg 1928: 177-187, 1931: 448). Kruusberg oli 1928. aastal veendunud, et „märatsemised, nagu valge laeva ootamine j.t., tulevad tema järelkäijate ja abiliste arvele panna, jutt ärasõidust pilvel võib prohveti jutluses vaga võrdlus olla, mis teisal pea peale pöörati” (1928: 181). Soome kirjandusteadlane Silja Vuorikuru on jõudnud Aino Kallase novelli „Lasnamäe valge laev” analüüsimisel intrigeeriva seletuseni, et „maltsvetlaste utoopia” oli „tooniandvalt naiste utoopia”, sest just naiste „pääsemiskogemuseks on argielu rõhuvust eitades saanud põgenemised utoopiasse" (Vuorikuru 2007: 182, 195). Kas ettekujutus valgest laevast oli sündinud taevaskäija Miina Reiningu utoopiana? Sellele ei ole võimalik mittekirjanduslike tekstidega vastata.

Valge laeva „imelik lugu” võeti eesti kirjanduses 1930. aastatel ${ }^{12}$ juba laialt omaks. Selle maltsvetlikus ehtsuses ei kahelnud kordagi ka usundiloolane Uku Masing, kes oma erakirjas tunnistas, et huvitus maltsvetlaste valge laeva ootuse tekkepõhjuste saladusest ja sümboli tähendusest (Masing 2012: 319). Masing tuletas valgest laevast eestlaste usundiloolise paranoia religiosa - „Valge Laev on enam kui hullunu fantaasia, ta on kogu meie rahva hinge sümbol...." (Masing 1993a: 142). Vilde ja Masingu ühisteeneks võibki lugeda seda, et valget laeva hakati pidama prohvet Maltsvetilt saadud rahvuslikuks sümboliks, mis on kujundatud eestlaste kultuuriruumis „üldrahvalikult tuntud metafooriks” ja mis tähistab „millegi ootamist, mille saabumise tõenäosus on kaduvväike kui mitte olematu" (Arula-Jahe 2005; Hinrikus 2014).

Vassar kordas 1975. aastal uuesti üle Kruusbergi poolt varem tõdetut, „et E. Vilde kirjeldus „valget laeva” ootavatest Järvamaa maltsvetlastest on liialdatud”. „Imelaeva” ootamisel oli reaalne tagapõhi ja eesmärk (Vassar 1975: $140,142)$.

12 1931. aastal nägi Kuressaares trükivalgust Jaan Metua neljavaatuseline näidend „Valge laev. 1905. aasta sündmused”. Samal aastal ilmus ka kordustrükk Aino Kallase „Valge laeva” tõlkest tema „Kogutud teoste” sarjas (esmatõlge ilmus kogumikus „Lahkuvate laevade linn”, 1913). Vt lähemalt Saard 2013: 1697-1701. 


\section{Vilde ja prohveti saladus}

Alttoa sõnul on varasemad uurijad heitnud Vildele ette, et ta polnud avanud Juhan Leinbergi prohvetiks saamise saladust ja maltsvetlaste usuliikumise olemust, seletades kõiki maltsvetlaste anomaalsusi sotsiaalsete oludega ja olude põhjustatud vaimse kängumisega, rahvaõnnetusena (Alttoa 1965: 132-133). „Võib läbi lugeda terve Maltsveti liikumise materjale käsitleva A. Kruusbergi teose „Materjale Maltsveti-liikumise kohta”, kuid prohveti saladust selles ei lahendata. Miks nõuti seda Vildelt?" küsib Viitol (2005: 102). Kruusbergi eesmärgiks ei olnud analüütiline süvapsühholoogiline prohveti isiku kujunemislugu, vaid allikakogumiku koostamine. Allikapublikatsiooni ja romaani eesmärgid on erinevad.

Vilde esitab romaanis Leinbergi prohvetiks saamisest kolm erinevat pärimust (1929a: 28-35). Karjakoplis ilmunud Juhanile ingel ja ulatanud talle prohvetliku kuldraamatu. Usundiloolasel Masingul polnud raske näidata, et pärimus on analoogne mormonismi ja adventismi sünnilooga (Masing 1993a: 118). Kaups pidas seda hilisemaks maltsvetlaste väljamõeldiseks, et tõsta prohveti autoriteeti. „„Õiglase loomuga” Leinberg ei oleks enda kohta sellist lugu levitanud," arvas Kaups (1936a: 133). Usundiloost leiab sellelegi seletusele analooge, kas või prohvet Muḩammadi näol, kellele jumal andis ilmutuse talletamiseks oskused. Teise versiooni kohaselt jäänud Leinberg Kostivere Loo kõrtsis leti taga magama, näinud leti all põrgutuld ja seal põlevaid tuttavate nägudega talupoegi, keda ta viinaga jootnud. Hommikul ärgates otsustanud ta kõrtsmikuametist loobuda ja meeleparandust kuulutama hakata. Juhan Luiga võttis Maltsveti „usuhaiguse” lahtiseletamisel aluseks just selle versiooni (Eesti Kirjanduse Seltsi ... 1910). Ka evangeeliumikristlasest usuloolane Ernst Ader on uskunud, et Leinberg koges seal mingit usulist elamust (Ader s.a. VII: 761). Kolmanda versiooni kohaselt aidanud Leinbergil kõrtsmikuametist loobuda tema vennastekoguduslasest sõber Tallinnast. Kaups peab kõige usutavamaks seda versiooni (1936a: 133). Ka Vilde pidas seda kõige tõetruumaks. Muud lood olid nende arvates legendid (Käosaar 1961: 83).

On olemas ka neljas pärimus, mida tundis ajaloolane Kruusberg. Hiljem laenas selle temalt oma arutlustesse Masing: Juhanile olevat kord ehitustöödel ${ }^{13}$ palk või tala pähe kukkunud, selle tagajärjel tekkinud tal hirm äkilise surma võimalikkuse ees ning sundinud teda meeleparanduse teele, nii et temast sai „ogar” ehk prohvet. Kruusberg kinnitas, et sellise seletuse andnud Leinberg kunagi ise, sest et „usuhaiguse puhkemise eel käib harilikult mingisugune hingeline põrutus, raske sisemine vapustus", nagu oli Luiga Maltsvetiga seoses juba varem tõdenud (Eesti Kirjanduse Seltsi... 1910; Kruusberg 1928: 179; 1931: 10; Masing 1993a: 115; Kronberg 2013: 25). On selge, et Kruusberg, kes Leinbergi surma ajal oli umbes kuueaastane, on kuulnud seda seletust hiljem. Traumad, põrutused, lähedalt mööda läinud (välgu)löögid, surma lähedus on religiooniajaloos mänginud kahtlematult olulist osa ja seda on võimatu ületähtsustada. Ka teoloog Johan Kõpp on tunnistanud: „Ihulistes raskustes ning hingelistes kannatustes valmib sünge hingelaad, kus enese puudulikkuses ning pattudes juurdlemisel saavutatakse sügavaid sisemisi vapustusi" (Kõpp 1926: 20).

Gustav Malts kirjeldab Leinbergi pöördumist kõigist eelkirjeldatuist erine-

${ }^{13}$ Võib-olla oli ta näiteks 1854. aasta veebruari lõpul Tallinna kindlustustöödel. 
valt. Pöördumine leidnud aset Tallinnas, siis kui Juhan ammugi enam kõrtsmikuametit ei pidanud, vaid kui ta jäi jooksvahaigeks ja palus endale tervist, lubades tervenemise korral vagamalt elama hakata, kauplemise ja kasu otsimise maha jätta ning rahvast piibli järgi elama õpetada. Aga ka Leinbergile lähedal seisnud Malts ei olnud tegelikult kindel, kas see kirjeldus oli detailides ammendav. Seepärast kirjutas ta, et olevat olnud veel teinegi kutsumise viis: Juhani 16-17-aastane tütar olevat leidnud tänavalt Uue Testamendi ja viinud selle isa kätte. Juhuslikust kohast avades jäi pöidla alla kirjakoht: „Tee aru oma majapidamisest” (Lk 16:2). See oli tuliste tähtedega kirjutatud. „Kust ta ial lugend ikka olnud otsegu tulised kirjad. Ta pannud imeks, ja lasknud teisi lugeda, aga need ei ole midagi iseäralikku näind, kui arilik trükki kiri.” Juhan sai terveks ja nägi unes, et vaim tuli ta juurde ja käskis antud tõotus tõeks teha (Malts: EVM 2002 Ar 1785, 1 86-87). Tallinnas asetleidnud Leinbergi „põhjalikku usulisse pöördumisse” uskusid ka Ader (Ader s.a. VII: 761) ja ajaloolane Tiit Rosenberg (1997: 60).

Leinbergi ajaloolis-folkloorsetes pöördumiskirjeldustes korduvad elementidena: hirm (põrguhirm, surmahirm), ilmutusliku teksti (ingli antud prohvetliku sisuga kuldraamat, tütre poolt tänavalt leitud Uus Testament) lugemine, meeleparandus (otsustamine, tõotamine). Kui üldiselt on püütud kõike tegelikkuses toimuvana esitada, siis kõik pöördelise tähtsusega seotu on paigutatud unenägude ja inglite sfääri. Äratuntavad on siin piiblist saadud mõjutused. Nii näiteks paigutuvad ka evangeeliumide Jeesuse sünnilood mitte tegelikkusesse, vaid unenägude ja inglite ilmutuste sfääri.

Vaatamata usulisele sisule romaan kiriklikes väljaannetes tähelepanu ei saanud. Esimesena reageeris Kroonlinna vaimulik Matthias J. Eisen, kelle jaoks tuli sellesisulise romaani ilmumine Vildelt suure üllatusena. Eisen polnud isegi teadlik, et „Prohvet Maltsvet” oli järjejutuna ilmunud juba mitu aastat Uudiste jutulisas. Tema arvates oli romaani pealkiri eksitav, sest analoogselt Saamueli raamatutega piiblis, mis kannavad küll Saamueli nime, aga räägivad temast vähe, oli ka romaani peategelasel Maltsvetil hoopis kõrvaltegelase roll. Romaani kõige suuremaks puuduseks pidas Eisen balansseerimist proosa ja ajaloolise kroonika vahel. Eisen soovitanuks Vildel kirjutada kaks eraldiseisvat teost, ühe ilukirjandusliku ja teise ajaloolise. Puuduseks pidas ta ka romaani anakronistlikkust, ja seda koguni kahel tasemel. Kõigepealt eksis Vilde, kui kritiseeris Jannsenit selle eest, et too ei suutnud olla eestlastele kohalik Adam Smith (Eisen 1908). Vilde heitis talle romaani lehekülgedel ette, et Maltsvetist kirjutades ei pööranud Jannsen mingit tähelepanu sotsioökonoomsetele teguritele ning nende puuduste kõrvaldamisele (Vilde 1985: 237). „Ei tohi me siis 1858. aasta sündmusi 1908. aasta mõõdupuuga mõõta, vaid 1858. aasta mõõdupuuga. 1858. aasta mõõdupuu ei näita ammugi nii suurt Jannseni süüd nagu kirjanik seda otsib," kirjutab Eisen. Kõige lõpuks aga pannakse romaanis „mõnigi liht talumees 50 aasta eest sedasama keelt rääkima, mis meil 1905 kõneldi” ja „iseäranis muudetud pildi saame, kui Vilde [Uudiste] prillidega usuelu hakkab tähele panema" (Eisen 1908). Vilde ajaloolistest romaanidest 1909. aasta jaanuari alguses Tallinna kultuuriseltsis Pandorin kõnelnud Bernhard Linde leidis, et romaan kannatas kõige enam just „poliitilise sihilikkuse all” (Kirjandus 1909).

„Ma oleksin ju peast hull olnud, kui ma 1860. aastal elanud eesti usuliialdaja ning tolleaegsete eesti talupoegade pähe sotsialistlikke aineid oleksin 
pannud või nende inimeste majandusliku liikumisega (muuseas väljarändamisega) midagi sotsialismi poole püüdvat oleksin tahtnud näidata... Mitte midagi sotsialismi poole sihitavat ei tule „Maltsvetis” ette. On ainult näidatud, kuidas usulise ülesehituse all majanduslik rattavärk kaasa töötab, kuidas orjatalupoegade ühishing usuliste ihade all, kas teadvusega või ilma teadvuseta, ikka (põhjast võttes) majandusliku vabanemise järele ihkab," seletas ja pihtis Vilde oma kirjas Kampmaale (Vilde 1957: 459). Romaani ülesandeks oli autori sõnul näidata, et hariduslikust madalpinnast ja majanduslikust vaesusest sündinud väljarändamisliikumine sünnitavad sektantlikke usuliikumisi (Vilde 1957: 274). „Usk näitas jälle kord, kui lähedalt ta kõhuga ühenduses seisab, kui väga ta pärit on sestsinatsest kurjast ainelisest ilmast” (Vilde 1985: 450).

Neist seletusist kumab läbi marksistlik vaateviis religioonile, mille järgi iga inimelu ja -mõtteviisi lähtekohaks on sotsiaalsed ja majanduslikud faktorid - sotsioökonoomia. Ideed ja väärtused on materiaalse tegelikkuse järelmid: religioon sünnib sotsiaalsest kurbusest (masendusest) ja majanduslikust ebaõiglusest.

Leinbergi isikus oli sulandatud tervikuks ajaloolis-folkloorne ja fantaasia. Selle tõsiasjaga aga ei ole tema prohveti- ja isiksusesaladuse avamisel alati arvestatud. Maltsveti isiksuse „usuhaiguse, paranoia religiosa” küsimust käsitleti esimest korda avalikkuses 1910. aastal Eesti Kirjanduse Seltsi koosolekul Tallinna reaalkoolis. Juhan Luiga esines seal 6. detsembril ettekandega „Prohvet Maltsveti elust ja tegevusest ning mõjust rahvale”. Luiga allikateks olid tema enda kogutud märkmed, aga põhilise osa moodustas sellest siiski Vilde romaan. ${ }^{14}$ Maltsveti prohvetisaladuse või „usuhaiguse” seletamisel jäi Vilde Luiga sõnul poolele teele, sest ei mõistnud tema hingeelu, püüdes teda romaanis esitada kui „majanduslist uuendajat”. Luigagi kinnitas, et „usuhaigust” oli eriti palju „majanduslikult kurnatud” eestlaste hulgas, aga Maltsveti prohvetlikku tegevust, mis algas „hingelise vapustusega”, pidas ta loomult puhtusuliseks. Luiga jõudis veendumuseni, et Maltsvet polnud „kelm ega petis", vaid toimis oma veendumuste põhiselt. Luigale sekundeerisid vaimulikud Villem Reiman ja Martin Lipp. Leiti, et Maltsvetil puudus vajalik jõud ja julgus oma mõtete ja õpetuste eest kannatajaks saada, mida tõendavat tema põgenemine Krimmi (Eesti Kirjanduse Seltsi... 1910; Omalt maalt 1910: 406). Lipp oli umbes kümme aastat varem kirjutanud: „Et Leinberg petis oleks olnud, kes meelega pettis, ei taha meie mitte uskuda” (Lipp 1899: 184).

Just Krimmi minekut, mis ei lasknud tal saada tõsiseks kannatajaks, heideti Maltsvetile ette, sest tõeline prohvet ei oleks saanud lõpetada teisiti kui märtrina. Ka Porkunis tegutsenud prohvetit Jakob Rosenbaumi peeti „suureks” alles siis, kui ta 1872. aastal Siberisse vangistusse saadeti. „Et Rosenbaumi nii rängalt karistati, tõestab tema „prohvetlikku suurust”," kirjutas köster Gustav Sandberg (Gustav Sandberg: EELKKA). Usundiloolane Masing oli teistsugusel arvamusel: „Maltsvetlased aga ei oodanud surma, vaid nad tahtsid põgeneda ära selle eest, nad tahtsid elada ainult, elada õieti ja vägevalt Jumala auks. Meie praegused vagad aga tahavad pääseda elu ja Jumala käest ning surra!" (Masing 1993a: 145.) Maltsveti prohvetitegevus kestis Jeesuse avalikust tegevusest pisut kauem - umbes kuus aastat (Wata, mis rummalus teeb! 1. 1861), millest intensiivset kuulutustööd Järvamaal (Ambla, Koeru, Järva-Jaani,

${ }^{14}$ Postimehes ilmunud ülevaates märgitakse ekslikult, et Maltsveti välimuse kirjeldus ja õpetused on leitavad Vilde romaanist „Mahtra sõda” (Eesti Kirjanduse Seltsi... 1910). 
Järva-Madise kihelkonnas) tegi ta umbes neli aastat. Kuulutuse intensiivsus, see, mis kuulutaja lõpuks läbi põletab, oli erinev. Jeesus suutis jumalariigi peatse saabumise kuulutamises vastu pidada pisut üle aasta ja lõpetas vägivaldse surmaga. Prohvet Maltsvet rahunes lõpuks ${ }^{15}$ ja elas viimased eluaastad tagasihoidlikult ning maeti kui „usuteatri väsinud näitleja” (Vilde 1985: 505) 72-aastasena 20. augustil 1885 kiriklikult maha (EAA 3159.1.417, kaader 60).

Kas säilinud allikmaterjalide põhjal saabki üldse midagi täpset öelda, millal Leinbergist sai prohvet? Jannsen teadis kirjutada, et Maltsvet tuli „prohveti mõtetega" juba Tallinnast (Järwa walle-prohwet 2. 1858). Arvatavasti oli ta 1855. aastast alates vaba alustama Järvamaal oma ringirändavat kuulutustegevust. Vennastekoguduste kommunikatsioonivõrgustiku abil olid kuuldused Maltsvetist 1857. aastaks jõudnud levida ka Pärnusse (Järwa walleprohwet 1. 1858). Järgmisel aastal kirjutas vennastekoguduslane Voldemar Jannsen prohvet Maltsveti Perno Postimehe veergudel üldtuntuks. Kriitiliste, naeruvääristavate artiklite avaldamise ajendiks sai Maltsveti vahistamine 26. septembril ja tema täitumata jäänud prohvetlik ennustus, et 1858. aasta 12. juunil saabub kohtupäev (Järwa walle-prohwet 3. 1858). Maltsvet jõudis 1859. aasta veebruari alguses Riiast tagasi Paidesse ja määrati koolmeistriks Kuusalus ja vaimuliku järelevalve alla. See meetod oli usuliselt aktiivsete vennastekoguduslaste peal juba minevikus äraproovitud ja oli aidanud allasurutud usulis-psüühilist energiat taltsutada, ning suunata kasulikku tegevusse (Vilde 1985: 192; Põldmäe 2011: 455).

Kinnivõtmine ja Riias toimunud ülekuulamised suurendasid Maltsveti autoriteeti. Kuid 1860. aasta teisel poolel võib näha prohveti aeglase rahunemise, eesmärgi puudumise aimatavaid tunnusmärke. 1860. aasta septembri lõpul või oktoobri alguses astub Maltsveti kõrvale Rannamõisa talutüdrukust taevaskäija Miina Reining, kes aitab prohvetil leida uue eesmärgi - liituda alanud väljarändamisliikumisega. Jumaliku käsuga seotud väljarändamine, Maltsveti Krimmi lahkumine järgmise aasta alguses, aga ka temast maha jäänud umbes kolmesajast perekonnast koosneva maltsvetlaste usuliikumise levitatud prohveti ennustus, et 1861. aasta suvel puhkev sõda hävitab suure osa Eestimaa rahvast, said põhjuseks, et Maltsvetist taaskord pikemalt kirjutada. Jannsen kirjutas veebruari lõpul seepärast kaks Maltsvetti naeruvääristavat artiklit (Wata, mis rummalus teeb! 1.-2. 1861).

Maltsvetiga enam-vähem samal ajal tegutses Porkunis 1850. aastatel vennastekoguduslasest rändpalvetundide pidaja Jakob Rosenbaum, kes kuulutas rahva peatset mõisaorjusest vabanemist. Rosenbaumi palvetunnid olid tulvil kuulajaid ja tema poolehoid ulatunud oma kodukihelkonnast kaugemale. Rahvas pidas teda prohvetiks. Rosenbaumil tekkis 1871. aasta 25. detsembril konflikt Väike-Maarja vaimuliku Carl T. Knüpfferiga, keda ta jutluse ajal oma viiulimänguga segas ja teotas: „Teie preestrid, ma panen teid Jumala needmise alla, kes mo vastu paneb jääb Jumala viha alla. Jah, seda ütlen ma pühas koijas" (EAA 902.1.1123).

Ennustused mõisaorjusest pääsemisest äratasid kohalike mõisnike ja võimude tähelepanu. 1872. aasta mai lõpul võeti 32-aastane Jakob kinni ja kaht-

${ }^{15}$ Veel 1869. aastal puhkenud Järvamaal Maltsveti õhutusel suurem „usumäratsus”, mis vaibus, aga ei kustunud täiesti. 1883. aastal põgenes Maltsvet Tallinna, sest oli Ambla kihelkonnas peetud palvetunnis kõnelenud midagi ilmalikest asjadest. Kubermangu politseivalitsus alustas sellepärast tema vastu juurdlust (Järva maakonnast 1883; EAA 29.2.5401, 11-3). 
lustatuna vaimuhaiguses suunati meditsiinilisse kontrolli. Komisjon, mille istungist võttis osa ka tollane ülemsuperintendent Woldemar Schultz, tunnistas Rosenbaumi normaalseks. Kohus mõistis ta aga rahvarahutustele ässitajana süüdi ja saatis Siberisse (EAA 862.1.7403a). „Et Rosenbaumi nii rängalt karistati, tõestab tema „prohvetlikku suurust” ja erilist mõju ümbruskonna rahvale. Ja seda mõju kardeti, sest „võim kardab vaimu”, kirjutas köster Gustav Sandberg, ja lisas, et „võrreldes Rosenbaumiga õnnestus Vildel päästa vähemalt mälestus prohvet Maltsveti tegevusest" (Gustav Sandberg: EELKKA).

Masing, kes ei ole nõus Schultz-Bertrami süüdistusega - et prohvet oli kelm ja petis, kelle sees oli „üks pettis pergel” ja kes ise oligi „kavval Sadan” (SchultzBertram 1866: 8-12) -, nägi Maltsvetis „üht vägevat meest” (Masing 2006: 233) ja maltsvetlastes õiget eestipärasust. Nagu oli näidanud Vilde, öelnud Kruusberg (1931: 6, 32) ja Juhan Luiga (1914: 1-3; 1918-1919: 141, 154; 1938: 315; 1995: 147, 173), ei olnud Maltsvet kõiges vaimselt terve. Masing võttis taolise ebanormaalsuse kui haruldase jumalalapseliku eestipärase siiruse oma erilise kaitse alla. Kahekümne viie aastase teoloogiamagistri Uku Masingu Vildet patologiseeriv märgistamine, et tal olevat olnud „haiglane vaen usu vastu” (Masing 1993a: 113), vajab siinkohal põhjendamist, sest kutselise usundiloolase hoiaku võtnud Masing ei vaevunud oma väidet põhjendama. Ta ei arvanud, et tema hoiak vajaks põhjendamist. Ja tagantjärele irooniana võib ainult märgiliseks pidada, et Masing, kes Vildesse nii kriitiliselt suhtus ja kellel säilis surmani „kiindumus usu vastu”, elas oma elu lõpuni Tartus Vilde tänaval.

Teoloog Johan Kõpp avas Maltsveti prohvetiks olemise saladust 1926. aastal aga hoopis niimoodi: „Nähtavasti on talle enesele tõesti mingi ilmutus osaks saanud, mis temale reaalsena tundus, niisama on mõistetav, kuidas täiesti usulises ümbruses, eriti Vennastekoguduse õhkkonnas kasvanud mees seda iseenesest mõistetavaks pidas, et rahva päästmine võib teostuda ainult kõige kõrgema võimu, Jumala, otsekohesel tahtel ning kaasabil. Mingisuguseid teiselaadilisi tegureid ei suutnud hariduseta ja väikese silmaringiga rahvajuht enesele ette kujutadagi. On ka näha, et M[altsveti] mõtteviis on aineid saanud iseäranis Vanast Testamendist, mis oma rahvaliku ning rahvuslise põhitooniga lihtsale vaimule iseäranis ligidal seisab ja arusaadav on. Miks ei võinud rahva hädadele kaasatundja, andekas ning osav mees, lugedes Iisraeli rahva imelikust pääsemisest, otsusele jõuda, et see, mis oli võimalik tuhandete aastate eest, peab võimalik olema hiljemgi samasuguses seisukorras viibiva rahva suhtes?" (Kõpp 1926: 82.) Teoloogiat õppinud kirjandusloolane Jaan Roos on romaani põhiprobleemi defineerinud kui müstilist „nälga Jumala järele” (Roos 1937: 80). Seda pidi väljendama siis kõik, nii vaimne kui ka materiaalne, kaasa arvatud vara mahamüümine ja võõrsile väljarändamine.

Ühtegi neist käsitlustest, kaasa arvatud Masingu oma, ei saa pidada lõplikuks. 1937. aastal pakuti usuteaduskonna auhinnatööde uurimisteemade hulgas välja teema: „Prohvet Maltsvet, tema isik, vaated, tähendus ja tegevus, eeskätt allikalise materjali alusel". Sama teema pakuti uurimiseks välja ka 1938. aastal, aga puuduvad andmed, kas keegi sellega ka tegelema hakkas (EAA 2100.5.24; Raid 1995: 135). 1939. aastal on usuteaduskonna aines „Usuline rahvateadus” olnud käsitletavate teemade hulgas ka näiteks usulised tegurid Vilde teoses „Prohvet Maltsvet” ja võrdlusena Aino Kallase jutustuses „Valge laev" (EELKKA Usuline rahvateadus 1939).

Folklorist Felix Oinas nägi prohveti väljarändamise juhiks saamise saladuse taga peamiselt ühe naise usku (ERA 5058.1.45; Oinas 1988: 39). Mitte 
lihtsalt ühe naise usk, vaid jumaliku pühavaimu täitumusega naise kindel usk. Missugune suur osa on naiste kindlal usul või ebausul olnud mõne uue usundi või usuliikumise tekkimisel, seda demonstreerib ilmekalt kristluse ajalugu ja kinnitab kirjanik Mait Metsanurga sõnu (1937: 334). Oinas jätkab, et „Vilde on oma romaanis andnud kannatava rahva fatamorgaana, vapustava pildi" (ERA 5058.1.45; Oinas 1988: 39).

Rein Veidemann on tõmmanud Juhan Liivi ja Maltsveti vahele võrduse - mõlemad on eestlaste prohvetid. „Liivile oli Eesti riik tõotatud maa metafoor. Ja see pakub võimaluse rääkida Liivist kui eestlaste prohvetist. Umbes samamoodi, nagu seda oli olnud prohvet Maltsvet," tõdeb Veidemann (2014: 121). Juhan Liivil oli pooleli käsikiri prohvet Maltsvetist, mille ta 1894. aasta veebruaris hullunult hävitas (Tuglas 1927: 235). Võib-olla oligi Liiv „eestlaste prohvet" ja teist ei olnud tema kõrvale enam vaja?

\section{Kokkuvõte}

Käesolev uurimus tõi varasemast selgemini välja, et lisaks Joosep Freimanni ja Gustav Maltsa käsikirjadele ning Perno Postimehes ilmunud maltsvetlust kriitiliselt käsitlevatele artiklitele on oluliseks maltsvetluse konstrueerimise allikaks olnud vabakoguduslikust, baptistlikust, spiritualiteedist laenatud uuestisündimise mõiste. Vilde püüdis 1880. aastatel sündinud prii- ja baptistikoguduste vaimulaadi abil tabada 1850. aastate lõpul sündinud maltsvetlaste vaimulaadi põhimustrit. Uuestisündimise, uuestiristimise ja iseseisva armulaua praktiseerimise kaasabil maltsvetlastest konstrueeritud pilt pole siiski autentne, sest kõik need kolm mõistet tulid kasutusele alles 1880-ndate alguses priiusuliste liikumises ja neist eraldunud baptistide kogudustes.

Kokkuvõtteks võib ka öelda, et nagu nähtub mitmesugustest dokumentaalsetest allikatest, ei sündinud valge laeva kujund Maltsveti ega ka abiprohvet Miina Reiningu fantaasias. See tekkis kas mõne ajaloo jaoks nimetuks jäänud maltsvetlase ettekujutustena või ka nende pilkamisena, mis hakkas ajakirjanduse kaudu 1861. aasta juunist alates levima. Vilde oma romaaniga kinnistas selle kujundi püsivalt nii inimeste mällu kui ka kirjandusse. Selle maltsvetlikus ehtsuses ei kahelnud kordagi ka usundiloolane Uku Masing, kes tuletas sellest eestlaste usundiloolise paranoia religiosa - kogu meie rahva hinge sümboli.

Juhan Leinbergi ajaloolis-folkloorsete pöördumiskirjelduste võrdlemine tõi paremini välja, et kõik pöördelise tähtsusega seotu on pärimustes paigutatud unenägude ja inglite sfääri, mis lubab järeldada, et nende loomisel on saadud mõjutusi Piiblist. Talletades seda pärimustikku romaani, sai Vildest Maltsvetist loodud folkloorse pärimuse unustusest päästja.

Lõppkokkuvõtteks tuleb tõdeda, et kuigi Vilde kogus nii Maltsveti kui ka maltsvetliku rahvaliikumise kohta suulist pärimust ja dokumentaalset materjali, ei kajasta tema teos mitte niivõrd ajaloolist Maltsvetti ja maltsvetlust, vaid illustreerib pigem marksistlikku religiooniteooriat, et religioossed liikumised sünnivad sotsioökonoomiliste tegurite mõjul. „Prohvet Maltsvetti” võib õigustatult nimetada eestlaste ängistusajaloo kirjanduseks.

Artikkel on seotud Kultuuriministeeriumi stipendiumiga teema „Kiriku ja usu küsimus Vilde ja tema lähedaste elus ning romaanis „Prohvet Maltsvet”” uurimiseks. 


\section{Arhiiviallikad}

EVM = Eduard Vilde Muuseum, 2002 Ar 1785 (G. Malts „Ajalugu Maltsveti usust ja Krimmi rändamisest”).

EAA = Eesti Ajalooarhiiv (mitmesugused fondid).

ERA = Eesti Riigiarhiiv, R-1707.1.139 P. Raudkivi stsenaarium „Viletsuse karavan” (sept 1953 - juuni 1955) Ed. Vilde romaani „Prohvet Maltsvet” ainetel.

ERA 5058.1.45 (Feliks Oinasega seotud materjalid).

EELKKA = Eesti Evangeelse Luterliku Kiriku Konsistooriumi arhiiv (Gustav Sandbergi (1887-1966) kogutud andmed Väike-Maarja kihelkonnas tegutsenud prohvet Jakob Rosenbaumi kohta ning tema tegevuse lühiülevaade).

EELKKA, Usuline rahvateadus 1939 II semester, käsikirjaline konspekt.

\section{Kirjandus}

A d e r, Ernst s.a. Eesti usuajalugu. VII ptk. Uuspietism ning vennastekoguduse tõus ja langus. Masinkirjas [Tallinn]. Käsikiri asub baptistide Kõrgema Usuteadusliku Seminari raamatukogus Tartus.

A d e r, Ernst s.a. Eesti usuajalugu. VIII ptk. Läänemaa ärkamine ja selle tagajärgi. Masinkirjas [Tallinn]. Käsikiri asub baptistide Kõrgema Usuteadusliku Seminari raamatukogus Tartus.

Alto (= Alttoa), Villem 1935. Eduard Vilde elu ja looming. (Keel ja kirjandus nr 16.) Tartu: Loodus.

A 1 t t o a, Villem 1965. Eduard Vilde. Tallinn: Eesti Raamat.

A r u l a - J a h e, Jette 2005. Valge Laeva tähendusest. - Sulane. Tallinna Kaarli koguduse ajakiri, juuli, lk 17-19.

Baptisti koguduse Usutunnistus ... 1912 = Baptisti koguduse Usutunnistus ja Põhjusseadus Pühakirja tunnistustega. Tallinn: J. Felsberg ja A. Tetermann.

Eesti Kirjanduse Seltsi... 1910 = Eesti Kirjanduse Seltsi kirjandusline koosolek Tallinnas. - Postimees 8. XII, nr 280.

E i s e n, Matthias Johann [= Dr. Ise] 1908. Prohvet Maltsvet. - Postimees 4. X, nr 18. Lisaleht: Kirjandusest.

H in rikus, Rutt 2014. Valge laeva muutumised. - Kirjanduspärand kultuuriloos. Artikleid ja uurimusi 2008-2014. Eesti Kultuuriloolise Arhiivi 85. aastapäevaks. Koost Marin Laak, Sirje Olesk. (EKLA töid kirjandusest ja kultuuriloost 7.) Tartu: Eesti Kirjandusmuuseumi Teaduskirjastus, lk 148-161.

H u h t a, Ilkka 2001. „Täällä on oikea Suomenkansa”. Körttiläisyyden julkisuuskuva 1880-1918. (Suomen kirkkohistoriallisen seuran toimituksia 186.) Helsinki: Suomen kirkkohistoriallinen seura.

Jõelähtme s.a. = Jõelähtme kiriku kroonika II. http://maarjakirik.ee/kogudus/ ajaluguvaimulikud/123-valmis-meie-kroonika-teine-osa (15. IX 2014).

Järva maakonnast. - Valgus 15. X 1883, nr 78.

Järwa walle-prohwet 1. 1858. - Perno Postimees 22. X, nr 17.

Järwa walle-prohwet 2. 1858. - Perno Postimees 29. X, nr 18.

Järwa walle-prohwet 3. 1858. - Perno Postimees 5. XI, nr 19.

K a u p s, Karl 1936a. „Prohvet Maltsveti” usuvaade ja selle mõju tänapäeva usuelu hinnangule. - Elukevade, nr 5/6, lk 131-134.

K a u p s, Karl 1936b. „Prohvet Maltsveti” usuvaade ja selle mõju tänapäeva usuelu hinnangule. - Elukevade, nr 7, lk 157-160. 
Kirjandus 1909. - Virulane 12. I, nr 8.

K i vi, Aleksis 2005. Seitse venda. Tlk Aivo Lõhmus. Tallinn: Eesti Raamat.

Kolmas kirri... 1861 = Kolmas kirri Järwa walleprohwetist ja temma eksitud jüngritest; Sõnnumed ommalt maalt. Tallinnast. Laeva-ootjad. - Perno Postimees 7. VI, nr 22.

K r o n b e r g, Janika 2013. Rännud kuue teejuhiga. Tallinn: Go Group.

K r u u s b e r g, Aleksander 1928. Sugemeid Maltsveti kui „prohveti” tegevuse kohta. - Ajalooline Ajakiri, nr 4, lk 177-187.

Kr u u s b e r g, Aleksander (toim) 1931. Materjale Maltsveti-liikumise kohta. Ajalooline arhiiv II. (Akadeemilise Ajaloo-seltsi toimetised VII.) Tartu: Loodus.

Kuusalu... 2014 = Kuusalu kirikukroonika 1837-1914. Die Kirchenchronik von Kusal. Väljaandjad Albrecht Rost, Toomas Mäeväli. Kuusalu: EELK Kuusalu Laurentsiuse Kogudus.

Kõ p p, Johan 1926. Usulisi liikumisi Eestis. (Soome-Eesti II üliõpilaspäevadel peetud kõne täiendatud kujul.) - Usuteaduslik Ajakiri, nr 1, lk 20-82.

Kä o s a a r, Juhan 1951. Eduard Vilde romaan „Prohvet Maltsvet” ajaloolise uurimusena ja kunstiteosena. - Eduard Vilde, Prohvet Maltsvet. Tallinn: Eesti Riiklik Kirjastus, lk 689-744.

K ä o s a a r, Juhan 1961. Gustav Maltsi käsikiri „Ajalugu Maltsveti usust ja Krimmi rändamisest”. - Keel ja Kirjandus, nr 2, lk 75-88.

L i p p, Martin 1899. Kodumaa kiriku ja hariduse lugu. Tõine raamat. Tõine anne. Jurjev.

Luiga, Juhan 1914. Juhan Leinberg. Psühhopatoloogilised mõjurid prohvet Maltsveti liikumises. - Eesti Kirjandus, nr 1, lk 1-3.

L u i g a, Juhan 1918-1919. Soome sugu usk. IV. - Eesti Kirjandus, nr 7, lk 129_ 155.

L u i g a, Juhan 1938. Haiguslikud ilmed terves inimhinges. - Eesti Arst, nr 5, lk 313-316.

L u i g a, Juhan 1995. Hingejõu ilmed. Koost Hando Runnel. (Eesti mõttelugu 6.) Tartu: Ilmamaa.

M a lt s, Gustav 2010. Ajalugu Maltsveti usust ja Krimmi rändamisest. - Methis, nr 5-6, lk 191-195.

M a lts, Gustav 2011. Ajalugu Maltsveti usust ja Krimmi rändamisest. - Tuna, nr 3, lk 115-129.

M a s i n g, Uku 1993a. Prohvet Maltsvet. - U. Masing, Vaatlusi maailmale teoloogi seisukohalt. Koost Hando Runnel. Tartu: Ilmamaa, lk 111-157.

M a s ing, Uku 1993b. Eestlase usulisi eeldusi ja nende tähendus teoloogiale. U. Masing, Vaatlusi maailmale teoloogi seisukohalt. Koost Hando Runnel. Tartu: Ilmamaa, lk 91-110.

M a s in g, Uku 2006. Uskuda, elada. 59 kirja Kiivitile. Tartu: Ilmamaa.

M a s i n g, Uku 2012. Kirjad Liile. Tartu: Ilmamaa.

M et s a n u rk, Mait 1937. Kutsutud ja seatud. Ühe hingekarjase päevik. Tartu: Noor-Eesti kirjastus.

O i n a s, Felix 1988. Lasnamäe valge laev. - Eesti Kirik, nr 1, lk 38-39.

Omalt maalt 1910. - Ristirahva pühapäevaleht 16. XII, nr 51.

$\mathrm{P}$ a a t s i, Vello 2011. Maakuulajate reis Krimmi ja Gustav Malts. - Tuna, nr 3, lk $130-131$. 
Pl a a t, Jaanus 2001. Usuliikumised, kirikud ja vabakogudused Lääne- ja Hiiumaal: usuühenduste muutumisprotsessid 18. sajandi keskpaigast kuni 20. sajandi lõpuni. (Eesti Rahva Muuseumi sari 2.) Tartu: Eesti Rahva Muuseum.

Protokoll... 1881 = Protokoll der Estländischen Provinzial-Synode. Reval: Gressel.

Põld mä e, Rudolf 2011. Vennastekoguduse kirjandus. (Eesti mõttelugu 101.) Tartu: Ilmamaa.

P ä r n a, Ants 1979. Meri ja mehed. Meresõidust Eestis. Tallinn: Valgus.

R a i d, Lembit 1995. Tartu Ülikooli Usuteaduskond 1632-1940. Teatmik. Tartu: Eesti Ajalooarhiiv.

R o o s, Jaan 1937. Ülevaade eesti kirjandusest. Keskkooli V klassile. (Keel ja kirjandus nr 42.) Tartu: Loodus.

R o s e n b e r g, Tiit 1997. Juhan Leinberg. - Eesti ajalugu elulugudes: 101 tähtsat eestlast. Koost Sulev Vahtre. Tallinn: Olion.

S a a r d, Riho 1995. Ühest äraunustatud Usutunnistusest. - Teekäija, nr 11, lk $6-8$.

S a a r d, Riho 1999. Ad fontes. L. Johannes Schwani kirjast Saaremaa ülemkirikueestseisjale N. von Ditmarile. - Teekäija, nr 11, lk 6-8.

$\mathrm{S}$ a a r d, Riho 2005. Eesti varase baptismi eneserefleksioonist. - Teekond teisenevas ajas. Peatükke Eesti vabakoguduste ajaloost. Toim Toivo Pilli. Tartu: Kõrgem Usuteaduslik Seminar, lk 9-28.

S a a r d, Riho 2013. Mida „nägi” Uku Masing? - Looming, nr 12, lk 1697-1701.

S a l u, Herbert 1981. Kuhu päike ei paista. Ühiskondlikke probleeme Eduard Vilde loomingus. Stockholm: Välis-Eesti \& EMP.

S c h u ltz - B e rtr a m, Georg 1866. Prohvet. - Peegli pildid. Peterburg, lk 8-12.

Simuna ... 2013 = Simuna kirikukroonika 1691-1919. Toim Janis Tobreluts. Põltsamaa: Simuna kogudus.

T u g l a s, Friedebert 1927. Juhan Liiv: elu ja looming. Tartu: Noor-Eesti kirjastus. Usso seggamisest 1865. - Eesti Postimees 29. IX, nr 39.

V a s s a r, Artur 1975. Uut maad otsimas. Agraarne ümberasumisliikumine Eestis kuni 1863. aastani. Eesti NSV Teaduste Akadeemia Ajaloo Instituut. Tallinn: Eesti Raamat.

Wata, mis rummalus teeb! 1. 1861. - Perno Postimees 22. II, nr 8.

Wata, mis rummalus teeb! 2. 1861. - Perno Postimees 1. III, nr 9.

V e i d e m a n n, Rein 2014. Arkaadia öö. Tallinn: Eesti Keele Sihtasutus.

V e n e, Ilmar 1987. Maailmatajust. - Looming, nr 2, lk 230-242.

V e n e, Ilmar 1997. Vahemere tuuled Hüperboreas. Tartu: Ilmamaa.

Vi it o 1, Livia 2005. E. Vilde „Prohvet Maltsvet”. Ilukirjandus ja dokument. Krimmi kogumik II. Konverentsi „Eestlased XIX-XXI sajandil Krimmis” ettekanded (9.-10. septembril 2004 Simferopolis). Koost Tõnu Tender, L. Viitol. Tallinn-Tartu: Eesti Keele Sihtasutus.

V i i t o l, Livia 2012. Eduard Vilde. Tallinn: Tänapäev.

Vil d e, Eduard 1904. Palve. - Uudised 7. IX, nr 79.

Vil d e, Eduard 1905. Prohvet Maltsvet. - Uudiste veste-osa 31. III, nr 26.

V i l d e, Eduard 1907. Iseenesest. 26. (13.) jaanuar 1907 Kopenhaagenis. - Eduard Vilde kirjatööde kogu. Tallinn: A. Pert'i trükikoda.

Vil d e, Eduard 1909. Proletarline või väikekodanline? - Päevaleht 20. III, nr 65. Vil d e, Eduard 1929a. Prohvet Maltsvet. I köide. Tartu: Loodus. 
V i l d e, Eduard 1929b. Prohvet Maltsvet. II köide. Tartu: Loodus.

Vi l d e, Eduard 1957. Artikleid ja kirju. Tallinn: Eesti Riiklik Kirjastus.

Vil d e, Eduard 1985. Prohvet Maltsvet. Tallinn: Eesti Raamat.

V u o r i k u r u, Silja 2007. Minä ikävöin maahan, jota ei ole. Utopia Aino Kallaksen novellissa „Lasnamäen valkea laiva”. - Nostalgia: kirjoituksia kaipuusta, ikävästä ja muistista. Toim. R. Rossi, K. Seutu. (Suomalaisen Kirjallisuuden Seuran Toimituksia 1137.) Helsinki: Suomalaisen Kirjallisuuden Seura, lk 168200.

W i e d e m a n n, F. J. 1869. Ehstnisch-Deutsches Wörterbuch. Petersburg.

\section{Vilde as the constructor of Maltsevism}

Keywords: Eduard Vilde, „The Prophet Maltsvet”, Maltsevism, Baptism, „White Ship"

This study proves, more than ever, that in addition to Joosep Freimann's and Gustav Malts' manuscripts as well as articles critical of Maltsevism, which appeared in the newspaper „Perno Postimees”, important material for constructing Maltsevism was acquired by borrowing the term „re-born” from Free Church and Baptist spirituality. Eduard Vilde investigated the spirituality of the Free and Baptist congregations born in Estonia in the 1880s, trying to discover the basic pattern of spirituality of the Maltsevians formed in the late 1850s. However, the construction of a picture of Maltsevism with „re-birth”, practice of rebaptism and an independent practice of the Lord's Supper, is not authentic because these three terms came into use only in the early 1880s among the Free Believers movement and the Baptist congregations that separated from them. As appears from various records, the image of the "White Ship” was neither a product of Maltsvet's nor his assistant-prophet Miina Renning's (prototype of the Miina Reining of the novel) fantasy. It was a result, perhaps, of the imagination of a Maltsevian who has remained anonymous or even of the mockery of the movement which circulated in newspapers since June 1861. Vilde's novel branded this image in people's minds as well as in literature. The authenticity of this powerful belief was never doubted by the religious historian Uku Masing, who thence derived the paranoia religiosa found in the Estonian history of religion as a spiritual symbol of our entire people. A closer look at Juhan Leinberg's (resp. Maltsvet's) historical-folkloristic descriptions of conversion provides a vivid evidence that anything of revolutionary importance is typically placed in the sphere of dreams and angels, thus leading one to conclude that Biblical influence has been at work in its formation. Thus, Vilde's novel saved from oblivion the folklore created around Maltsvet. In conclusion, although Vilde collected material from oral sources and documented material about Maltsvet as well as the movement inspired by him, his novel does not describe the historical person or movement; rather, he illustrates a Marxistic theory of religion where religious movements are born as a result of socio-economic factors. „The Prophet Maltsvet" can truly be called a description of the Estonian history of oppression.

Riho Saard (b. 1961), ThD, Universities of Helsinki and East Finland and Estonian Evangelical Lutheran Church Institute of Theology, docent, rihosaard01@gmail.com 